\title{
Diffusing new technology without dissipating rents: some historical case studies of knowledge sharing
}

\section{James Bessen ${ }^{1}$ and Alessandro Nuvolari ${ }^{2, *}$}

${ }^{1}$ Boston University School of Law, Technology and Policy Research Initiative, 765 Commonwealth Avenue, Boston, MA 02215, USA. e-mail: jbessen@gmail.com and and ${ }^{2}$ Sant'Anna School of Advanced Studies, Institute of Economics, Piazza Martiri della Libertà 33, Pisa 56127, Italy. e-mail: alessandro.nuvolari@santannapisa.it

*Main author for correspondence.

\section{Abstract}

The diffusion of innovations is supposed to dissipate inventors' rents. Yet in many documented cases, inventors freely shared knowledge with their competitors. Using a model and case studies, this article explores why sharing did not eliminate inventors' incentives. Each new technology coexisted with an alternative for one or more decades. This allowed inventors to earn rents while sharing knowledge, attaining major productivity gains. The technology diffusion literature suggests that such circumstances are common during the early stages of a new technology.

JEL classification: N70, 033, 034

\section{Introduction}

Economists of innovation have noted, with some surprise, that inventors sometimes freely exchange knowledge with their competitors. Knowledge sharing among inventors seems surprising because the uncompensated diffusion of technology—whether by imitation, "spillovers," or willful sharing—is supposed to dissipate innovators' rents. ${ }^{1}$ That is, standard theoretical models assume that diffusion allows rivals to drive down prices, reducing or completely eliminating the profits that the original innovator can make from the innovation. Willful sharing of technical knowledge, facilitating the free diffusion of a new technology, would thus, according to traditional economic reasoning, seem harmful to the innovator. Although knowledge sharing can offer some benefits to innovators, especially when this behavior is reciprocated by other inventors, rent dissipation is typically assumed to outweigh any such benefits. In other

1 It is, of course, widely recognized that firms can protect their innovations against imitators without using patents. Trade secrecy, first-mover advantages, and leverage from complementary goods and services might limit or slow diffusion (Levin et al., 1987). However, the puzzle posed by knowledge sharing raises a different issue, namely, that diffusion of knowledge itself does not necessarily dissipate the innovator's rents. That is, the historical episodes of knowledge sharing are not cases where innovators found ways to make their inventions excludable without patents; rather, that excludability of the inventions was itself not particularly valuable to profiting from innovation. 
words, only in exceptional circumstances would knowledge sharing seem congruent with the pursuit of standard economic self-interest.

Yet an accumulating body of evidence suggests that knowledge sharing between innovators is not at all exceptional. "Open Innovation" may be a recent management fad and open-source software may be a recent development, but innovators have shared knowledge of their inventions since the nineteenth century and possibly even before. Allen (1983) was the first to identify knowledge sharing during the nineteenth century in the form of "collective invention," which he documented in the British iron industry in the Cleveland district. Allen (1983: 21) speculated that "under the conditions prevailing during the nineteenth century, [collective invention] was probably the most important source of inventions". Since Allen, scholars have identified many other examples of knowledge sharing (Bessen and Nuvolari, 2016). Although most past episodes of knowledge sharing were limited in time and geography, they were responsible for major technological improvements in key technologies such as textile machinery, steam engines, and iron and steel production. This is significant because it suggests that conventional notions about innovation incentives and diffusion might not be universally applicable.

In attempting to explain knowledge sharing, most of the literature has focused on the possible benefits of sharing. ${ }^{3}$ But if sharing knowledge with rivals dissipates rents, then these benefits would have to be exceptionally strong in order for innovators to share despite the loss of rents. Recognition of these benefits does not explain why sharing episodes have occurred frequently and also why they often have only been temporary. ${ }^{4}$

This article offers a complementary explanation and verifies its relevance in three historical case studies. We argue that innovators can earn rents even while sharing a new technology if that technology coexists with an older, inferior alternative. The intuition is that before a new technology completely replaces the old, the old producers substantially determine the market price. The market price will be significantly higher than the marginal cost of production using the new technology. This high price allows producers using the new technology to earn supra-normal profits and, in this context, sharing knowledge of improvements does not dissipate these rents. Furthermore, in this context, knowledge sharing results in further technological advance by means of streams of incremental innovations.

The co-existence of old and new technologies, the prolonged process of diffusion and adaptation of new technologies, and the critical role of incremental technical progress are precisely critical features of innovation processes highlighted by Rosenberg in several key contributions (Rosenberg, 1976, 1982). Rosenberg (1976: 189) noted that "the rate at which new techniques are adopted and incorporated into the productive process is without doubt, one of the central questions of economic growth" and formulated several explanations accounting for the co-existence of different vintages of technology and for the delays in the diffusion of new technologies, including the nature of capital replacement, user heterogeneity, and user learning about the technology. These explanations are generally consistent with our model, suggesting that early adopters might well have had opportunities to earn rents, making knowledge sharing advantageous in rather common circumstances.

We test whether this explanation applies to three significant episodes of knowledge sharing from the nineteenth century. We find that during these episodes

- firms using new technologies continued to earn high profits for one or more decades despite knowledge sharing and diffusion;

- they also made dramatic productivity gains, via the streams of incremental improvements highlighted by Rosenberg (1976: 77-79) then, suggesting that innovation incentives remained strong and that knowledge sharing was an important source of technological progress;

- where inventors obtained patents, the patents generated relatively small rents, suggesting that market exclusion was not valuable then; and

- new technologies coexisted with alternative inferior technologies for extended periods, pointing to the existence of significant constraints on the implementation of the new technologies (Rosenberg, 1976: 195-207). A common

2 See Penin (2007) and Powell and Giannella (2010) for useful surveys. On innovation commons, see Allen and Potts (2016), and on collaborating networks of inventors, see Benkler (2017).

3 Penin (2007) surveys this literature.

4 Gambardella and Hall (2006) provide a model for software where knowledge sharing ends when lead innovators obtain greater rewards from proprietary control of their innovations. The model in this article explains why the advantages from private use of knowledge might overcome the benefits of sharing. 
constraint was the limited supply of people with the practical knowledge and skills to build, install, operate, and maintain the new technologies (Rosenberg, 1976: 197-199).

Thus, rents did not substantially dissipate for reasons consistent with our proposed explanation. More generally, the case studies highlight the diversity of conditions under which innovation occurs and, consequently, the need for analysis and policy that reflect specific conditions. ${ }^{5}$ Adaptable innovation policies might be especially important during the highly critical early stages of new technologies, when major technological innovations are made. Such policies might involve more than patents and, perhaps, significant limitations on the scope of patents.

\section{A model of technology coexistence and knowledge sharing}

To analyze the case studies, we propose a general explanation for why rents might not substantially dissipate during these phases of knowledge sharing and why knowledge exchange might be privately beneficial to innovators. We then compare observed behavior with the behavior predicted by our model.

\subsection{Benefits}

It is not hard to identify potential benefits that arise when innovators exchange knowledge. For example, some case studies below illustrate situations where different innovators have developed complementary improvements in different steps of a production process. Mutual exchange allows them to combine complementary innovations, improving productivity (see also Harhoff et al., 2003). Even the simple exchange of performance data can have benefits by allowing the identification of best practice designs (Allen, 1983; Nuvolari and Verspagen, 2007). Other benefits include enhanced reputations of engineers and mechanics (Allen, 1983, Lerner and Tirole 2003; Nuvolari, 2004,) or enhanced value of specialized assets (Allen, 1983). In any case, our main focus here is on the other side of the costbenefit calculation, namely, the dissipation of rents presumed to result from sharing information with rivals, with or without expectations of reciprocity.

\subsection{Dissipation of rents}

This dissipation of rents is typically assumed to be so harmful as to outweigh any benefits of sharing or mutual exchange. A standard assumption of almost the entire theoretical literature on innovation is that imitation dissipates rents, or more specifically, that imitation completely dissipates rents. ${ }^{6}$ Thus, Nordhaus (1969) assumes that an innovator earns zero rents after the patent expires. This is also a feature of the patent race models of Loury (1979) and Lee and Wilde (1980) and the industrial structure investigation of Dasgupta and Stiglitz (1980). Dissipation is assumed to occur because imitators expand industry output, driving down the equilibrium product price. In the worst case, imitators freely enter, driving the product price down until it equals marginal cost, eliminating all rents. Moreover, this argument applies to not only imitation but also other sorts of uncompensated diffusion, including inadvertent "spillovers" as well as intentional knowledge sharing.

The assumption that free diffusion dissipates rents seems highly plausible, but there is little actual evidence that this assertion is universally true, especially regarding the complete dissipation of rents. Indeed, the literature on technology diffusion suggests that firms can earn rents even with freely available technology. Consider, for example, Salter's (1960) model of delay in the adoption of new techniques. Salter explored the lags in the adoption of blast furnace techniques and built a theoretical model to explain the phenomenon. In his model, producers using the new technology earn rents, whereas other producers continue to use older, technologically inferior vintages. The market for pig iron is competitive so that the market price equals the marginal cost of production of the oldest vintage in use. Then producers using the new technology earn rents equal to the cost advantage of the new technology, that is, the difference between the marginal cost of production using the old and new technologies. When different vintages

5 Again, we find this consideration fully in line with Rosenberg's plea that a proper assessment of the economic effects of technical change should pay due attention to the specific salient features of the technologies in question (Rosenberg, 1982: 7).

6 An important exception is Boldrin and Levine (2008). 
coexist, knowledge sharing might be feasible. Braguinsky and Rose (2009) and Bessen (2011) develop specific models where knowledge sharing occurs when new and old technologies coexist. ${ }^{7}$

\subsection{A simple model of coexistence}

We can identify some common characteristics in these diffusion models that allow us to build a very simple model of coexistence. The model shows that when different technology vintages coexist, innovators can earn rents even with the free diffusion of technology.

Consider two technologies that can be used to produce an identical product. These technologies have different constant marginal costs, $c_{0}$ and $c_{1}$, such that $c_{1}<c_{0}$. That is, Technology 1 provides a cost-reducing improvement over Technology 0 . We refer to Technology 0 as the "old" technology and Technology 1 as "new." There is no particular significance to these designations; the two technologies might be described simply as "alternatives" instead. The model can be readily extended to cover multiple vintages, product quality improvement, and product differentiation, but the main insights are revealed in this simpler version. Assume that each unit of output from both technologies requires a unit of capital at rental rate $r$. Capital costs are sunk and the rental rate includes depreciation plus the return to investors.

Our first general assumption is that there are significant switching costs from Technology 0 to Technology 1 so that the old technology cannot be economically upgraded with a retrofit. If there were no substantial switching costs, then producers with sunk investments in Technology 0 would upgrade to Technology 1 and then the two technologies would not coexist in the marketplace. Many models impose switching costs by assuming that technology is embodied in capital. Our assumption includes embodied capital but is more general.

Assume that markets for both technologies are competitive. ${ }^{8}$ The new technology might be protected by patents, but, if so, we assume that the patents are licensed to multiple competing parties and that the licensing cost is included in $c_{1}$. Let the standard inverse demand function for the good produced by the two technologies be $P(Q)$, where $Q$ is aggregate output and $P^{\prime}(Q)<0$.

In this case, the market price before Technology 1 is introduced would be $p_{0}=c_{0}+r$ and output would be $Q_{0}$ such that $P\left(Q_{0}\right)=Q_{0}$ (see Figure 1). If the new technology completely replaced the old technology, the market price would be $p_{1}=c_{1}+r<p_{0}$. Clearly, if firms using the new technology could freely enter or could produce at sufficient scale, they would completely drive the old technology out of the market. In order for the two technologies to coexist for a period, it is necessary to make a second general assumption. Specifically, while the technologies coexist, some constraints must apply to the deployment of the new technology, both a constraint on the entry of new firms and a constraint on the scale of operations of any firm using the new technology.

Logically, such constraints appear to be implicit assumptions in many of the models of technological diffusion. In Salter's model, firms only make limited investments in the latest vintage, apparently because some constraint is at work. In diffusion models where complementary assets play a central role, apparently the supply of those assets is limited. For example, the use of a new mining technology might be limited by the available mineral deposits or the use of tractors might be limited by the supply of suitable farmland. Other models are based on heterogeneous firm characteristics, such as the technology-specific knowledge of managers. But that knowledge can also be viewed as an

7 The literature on capital replacement and technology diffusion provides other models with other reasons why different vintages of technology might coexist for extended periods. In some models, the investment decision is shaded by expectations about the rate of technological improvement and the corresponding rate of technological obsolescence; see Brems (1968), Williamson (1971), Kamien and Schwartz (1972), and Rosenberg (1982: 104-119). Bessen (1999) models expectations using real options. Diffusion lags might involve investments in complementary assets in addition to investments in new capital goods, including investments in interrelated technologies (Frankel, 1955), specific human capital (Chari and Hopenhayn, 1991), learning-by-doing (Parente, 1994; Jovanovic and Lach, 1989), and search (Jovanovic and MacDonald, 1994). Mokyr (1976) provides a "growing up" model of industrial development where a new technology sector coexists with an older technology, the pace of replacement determined by the rate of investment in new technology.

8 Assuming, instead, that firms have market power adds complications that might result in dissipation of rents with knowledge sharing. For example, in Reinganum (1983), a monopolist incumbent using inferior technology might coexist with a new technology, as long as the benefits of the new technology are not too great. In this case, the addition of an imitator using the new technology would affect prices and would diminish the innovator's rents. 

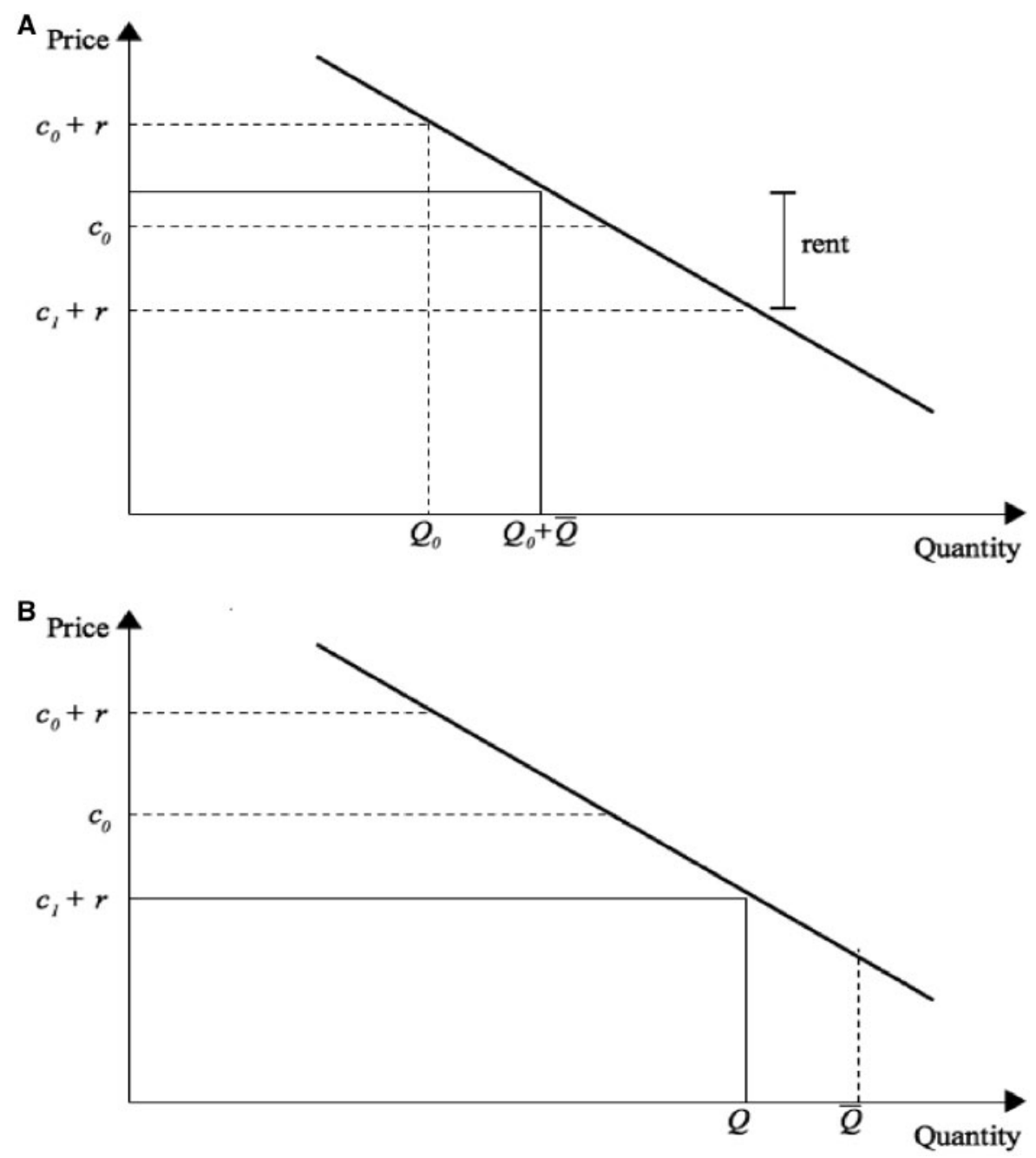

Figure 1. Coexistence and replacement equilibria. A. Coexistence (I). Capacity constraint on new technology permits old producers to remain in the market. Old producers make sub-normal returns, while new producers earn rents. B. Replacement (IV). Capacity constraint no longer binds, allowing new producers to replace old, but now earning only normal returns.

asset constrained to a limited supply. Furthermore, capacity constraints of this kind are also recurrent in many historical accounts of technological diffusion (Rosenberg, 1976: 189-210).

A simple way to model these constraints is to suppose that the aggregate output of firms using the new technology is less than a limit, $\bar{Q}$. The constraint could be modeled in a more sophisticated way by positing an input to the production function that has an inelastic supply curve. However, as long as the supply of that input is sufficiently inelastic, the results will be roughly the same as with our simpler assumption.

This setup generates equilibrium regions where the new technology coexists with old and other regions where it replaces the old. To keep things simple, consider the case where $c_{0}>p_{1}$, that is, the new technology is sufficiently drastic to potentially replace the old. ${ }^{9}$ Then there are four equilibrium regions, in declining order of market price (increasing output):

9 When this condition does not hold, there is no replacement region, but similar regions where the old and new technologies coexist. 
1. Coexistence without replacement: If $p_{0}>P\left(Q_{0}+\bar{Q}\right)>c_{0}$, the technologies coexist and the new technology firms earn positive rents ${ }^{10}$ equal to $P\left(Q_{0}+\bar{Q}\right)-c_{1}-r>0$. The old technology firms earn positive profits (quasirents), but these provide less than the normal rate of return on their sunk capital investments (see Figure 1A).

2. Partial coexistence: If $P(\bar{Q})>c_{0} \geq P\left(Q_{0}+\bar{Q}\right)$, then the new technology firms coexist with some of the old technology firms, but some old technology firms exit (or reduce production) until the market price just exceeds $c_{0}$. The new technology firms earn positive rents equal to $c_{0}-c_{1}-r>0$.

3. Constrained replacement: If $c_{1}+r<P(\bar{Q}) \leq c_{0}$, the new technology completely replaces the old. In this case, the new technology firms earn rents of $P(\bar{Q})-c_{1}-r$.

4. Replacement with free entry: If $P(\bar{Q}) \leq c_{1}+r$, then the constraint no longer binds, the market price equals $p_{1}=c_{1}+r$ and firms earn no rents (see Figure $1 \mathrm{~B}$ ).

The intuition in the coexistence regions is that the output constraint permits old technology firms to earn nonnegative profits at a price that is above the marginal cost of the new technology. Figure 1A shows the coexistence equilibrium (1) where the equilibrium price, $P\left(Q_{0}+\bar{Q}\right)$, is greater than the old marginal unit cost. In this case, firms using the old technology are not forced out of the market, but they fail to earn the normal return on their capital; firms using the new technology earn positive rents. In Figure 1B, the capacity constraint no longer binds, the old technology is completely replaced and firms earn no rents in the competitive market using the new technology. Thus, under assumptions that appear to be implicit in most of the technology diffusion literature, we find that firms with new technology earn rents even though they share a common technology. This result is not very surprising, but it emphasizes that the common assumption of free entry and unconstrained deployment of the new technology is at odds with the commonly observed coexistence of new and old technologies.

\subsection{Knowledge sharing and patents}

Now let us modify this setting to explore whether firms will be willing to share a technological improvement with rivals. Suppose in the above setting that there are two firms of equal capacity that use the new technology, $a$ and $b$, each having a maximum output of $\bar{q}=\bar{Q} / 2$. Now suppose that firm $a$ develops an improved version of the technology with a constant marginal unit cost of $c_{2}<c_{1}$. Assume further that everything else remains the same and that firm $b$ could switch to this new technology at zero cost (old technology firms still cannot switch). Does it make sense for firm $a$ to share its technology with firm $b$ in the coexistence equilibria (1 and 2)?

First, it is easy to show that sharing knowledge does not harm firm $a$ in the coexistence equilibria. In Equilibrium I, firm $a$ earns rents of $P\left(Q_{0}+\bar{Q}\right)-c_{2}-r$ regardless of whether firm $b$ has marginal cost of $c_{1}$ or $c_{2}$. Similarly for Equilibrium II. Consequently, in these coexistence regions (and Region III), sharing knowledge does not reduce rents. Given positive benefits from knowledge exchange—or unilateral sharing with expected reciprocation—firm $a$ will benefit from knowledge sharing. This does not mean that sharing is $a$ 's best choice, however.

Alternatively, firm $a$ could patent the improvement and license it to firm $b$. Assuming a Nash bargaining solution, firm $b$ would pay a unit royalty of $\frac{c_{1}-c_{2}}{2}$ so that the total value of the patent in Regions I and II is $\frac{\left(c_{1}-c_{2}\right) \bar{Q}}{4}$. As this quantity is positive, firm $a$ would choose to patent and license the improvement in this simplified setting. If, on the other hand, there are significant information asymmetries or transaction costs, then patent licensing might be too costly. This might be especially true if both firms $a$ and $b$ expect to make a series of improvements to the technology. Under these conditions, knowledge sharing with expected reciprocation might be the preferred choice when new and old technologies coexist.

The result is different, however, when the new technology replaces the old, as in Region IV. Here it pays to exclude firm $b$ from using the improvement as in the conventional argument. If firm $a$ freely shares the improvement, then neither firm earns positive profits. On the other hand, assuming that the improvement is nondrastic, firm $a$ can earn rents of $c_{1}-c_{2}$ per unit output by not sharing it. ${ }^{11}$ The value of the patent would then be $\left(c_{1}-c_{2}\right) Q$ over four

10 These rents would be considered "quasi-rents" if the constraint were temporary. This is often, but not always, the case. We will describe the supra-normal profits as "rents" to keep terminology simple.

11 In the nondrastic case, the monopoly price using the improvement exceeds. With a drastic innovation, firm a would find it even more profitable to expand its output to the monopoly level (the original equilibrium output is below the constraint). 
Table 1. Three historical case studies of knowledge sharing

\begin{tabular}{|c|c|c|c|}
\hline & Power weaving & Bessemer steel & Cornish engines \\
\hline Duration & 1817-1833 & $1867-1877$ & $\begin{array}{l}1811-1904 \text { (publication } \\
\text { of Lean's Reporter ), but } \\
1811-1870 \text { is probably } \\
\text { the "glorious" phase }\end{array}$ \\
\hline $\begin{array}{l}\text { Coexisting products } \\
\text { (initial) }\end{array}$ & $\begin{array}{l}\text { Handloom weaving, British } \\
\text { imports, wool, linen }\end{array}$ & $\begin{array}{l}\text { Iron rail, British } \\
\text { imported rail }\end{array}$ & $\begin{array}{l}\text { Other mining methods } \\
\text { (overseas) }+ \text { co-existence } \\
\text { of different vintages in } \\
\text { Cornwall }\end{array}$ \\
\hline $\begin{array}{l}\text { New technology } \\
\text { market share at end } \\
\text { of sharing episode }\end{array}$ & Almost all & $\begin{array}{l}57 \% \text { in } 1877 ;>90 \% \\
\text { by } 1883\end{array}$ & $\begin{array}{l}10 \% \text { of world market } \\
1861-1870\end{array}$ \\
\hline Constraints on scale & Knowledge & Knowledge & $\begin{array}{l}\text { Geology + engineering } \\
\text { skills }\end{array}$ \\
\hline Profits from operations & $\begin{array}{l}\text { Textile mills, dividends } \\
\text { to capital: } \\
8.0 \%-27.5 \%(1817-1826) \text {; } \\
5.0 \%-13.8 \%(1827-1836) \\
\text { Machine shop, sales margin: } \\
23 \%-33 \%(1820-1830)\end{array}$ & $\begin{array}{l}\text { Annual profits: } \\
20 \%-130 \% \text { of capital }\end{array}$ & $\begin{array}{l}\text { Sales margins: } \\
25 \%-44 \%\end{array}$ \\
\hline Productivity gains & $79 \%$ less labor time/output & $\begin{array}{l}78 \% \text { reduction in price } \\
\text { of steel rail less price of } \\
\text { pig iron }\end{array}$ & See Figure 4 \\
\hline Patent royalties / profits from operations & $<1 \%$ & $<3 \%$ (original patents) & No patents \\
\hline
\end{tabular}

times larger than in the coexistence case. ${ }^{12}$ Clearly, the benefits of sharing would have to be exceptionally large for firm $a$ to forego these rents.

This simple model can explain why firms might share knowledge when new technology coexists with old. Moreover, it can explain why sharing episodes might be temporary if constraints eventually ease. If this model accurately describes behavior in the case studies, then we should expect knowledge sharing episodes as characterized by these salient features:

- Coexistence: Knowledge sharing should occur when new and old technologies coexist and would end when the old technology is completely replaced.

- Constraint: Coexistence depends on a constraint and should end when that constraint eases.

- Profits and innovation: During the sharing episodes, new technology firms should earn above normal profit margins and they should have strong innovation incentives, hence ongoing innovation.

- Patents: During the sharing episodes, patents might not be particularly valuable; they should become more valuable when coexistence ends.

In the following, we will check to see whether the case studies do, in fact, exhibit these patterns of behavior. Table 1 summarizes the findings from each case study on these points.

12 The equilibrium output level in Region IV is larger than in Region II, as the market price is lower. This calculation assumes either that firm a excludes firm $b$ from the market, producing all of the output, assuming that its capacity constraint does not bind. Alternatively, firm a licenses its patent to $b$, under the threat of excluding $b$. In this bargaining problem, firm a has all the bargaining power and collects all of the rents. If capacity constraints prevented firm a from entirely replacing firm $b$, then the value of the license would be somewhat less. 
The model, of course, is not a complete explanation and other factors may surely affect knowledge sharing. However, if the case studies fit the model, then it suggests that common conditions may give rise to knowledge sharing.

\section{Case studies}

\subsection{Power weaving}

\subsubsection{Coexistence}

Automation of textile weaving, especially for cotton, was one of the most important technological advances of the Industrial Revolution. During the late 1790s, the first power looms were put into operation in Britain (Allen, 2018). Beginning no later than 1810, American inventors began developing power looms. These inventions were influenced by British designs, but they diverged significantly as American inventors made distinct improvements and adaptations (Zevin, 1971; Jeremy, 1981). The design that eventually dominated the US cotton textile industry was developed by William Gilmour, an immigrant mechanic who had experience with textile equipment in Scotland. Arriving in New England in 1815, Gilmour contracted to build weaving equipment for Judge Lyman of the Lyman Cotton Manufacturing Company in 1816 (Bagnall, 1893). A year later, the loom was in operation.

But Gilmour did not patent this loom. ${ }^{13}$ Instead, he shared the design with David Wilkinson, a prominent Rhode Island mechanic who had helped him, charging him a modest amount (\$10) for his drawings (Bagnall, 1893). And Judge Lyman encouraged the use of the loom by other manufacturers. Wilkinson and Gilmour went into the business of building textile equipment for these manufacturers. Gilmour also benefited from a $\$ 1500$ subscription subsequently raised by cotton manufacturers to reward him for his important contribution.

This was not the only case of knowledge sharing during the first two decades of power weaving in the United States. In Gilroy's review of US weaving technology published in 1844, some inventions were patented and some were not. The Boston Manufacturing Company (BMC) began by obtaining patents and licensing them out but drastically switched course after a few years. Paul Moody's inventions in power transmission were widely shared. Nor was the weft fork, the most important invention of the 1830 s, patented. ${ }^{14}$ On the other hand, Ira Draper did patent two versions of a loom temple that were widely used.

Consistent with the model, power weaving coexisted with alternative technologies during this period when knowledge sharing occurred. Cotton cloth woven by power looms initially competed against several substitutes: cotton cloth woven on handlooms, wool and linen, and British imports, which were subject to heavy tariffs. Power weaving unit costs were much lower than handloom rates, however. Not surprisingly, power weaving capacity grew rapidly during the first two decades, so that by 1833 , power weaving had completely replaced handloom weaving and British imports of coarse cloth (Zevin, 1971) and the growth of power weaving production slowed. ${ }^{15}$

After coexistence ended during the 1830s, so did extensive knowledge sharing, apparently. The significant inventions of the 1840s and 1850s were all patented. ${ }^{16}$ Manufacturers still exchanged some knowledge, for example, at the meetings of the National Association of Cotton Manufacturers, but technical designs were no longer freely shared. Although other factors were likely involved in the change in behavior as rivalry between power weaving mills

13 Gilmour later obtained a patent for a loom in 1820, although little is known about this design. Under patent law it had to be different than the model introduced in 1817.

14 Gilroy himself claims to have invented the weft fork in 1831 but did not patent it (Gilroy, 1844: 416). Ramsbottom and Holt patented a version in 1834 in England, but they did not patent it in the United States, perhaps because of Gilroy's prior art. There was no US patent claiming a similar device in the United States until Stillman in 1841. Even if one discounts Gilroy's claim, unpatented versions were in use in the United States. The weft fork was used first in the manufacture of fine cloths and only later for coarse cloth production.

15 British imports of fancy cloths, a relatively small part of the market, were not entirely replaced by then, however. Zevin finds that cotton cloth production at the mills grew $42.1 \%$ per annum from 1815 to 1824 and $17.1 \%$ per annum from 1824 to 1833 . After 1833 , he finds the growth was only $5.1 \%$ per annum.

16 Draper (1907) cites the automatic let-off (the Barlett motion patented in 1857) and parallel picker (patented 1851 and 1859 ) in addition to the weft fork as the most important inventions. Other important inventions include Bigelow's combination of weft fork and brake and let-off that "held at the beat" (both patented in 1856). 
intensified, knowledge of the new technology was shared when it coexisted with more costly alternatives and sharing ceased when those alternatives were completely replaced.

\subsubsection{Constraint}

Why did it take two decades for power weaving to replace inferior alternatives? The mechanical drawings were available and no special natural resources or inputs limited production. Zevin (1971:144) argues that there was a limited supply of people with ability to "build, install, operate, and maintain the new machinery." The design of the power loom was only one part of the total knowledge involved in the implementation of the technology. Indeed, Gilmour was unable to make his own loom work until a weaver who had experience on English looms showed him how (Bagnall, 1893). Bessen (2003, 2012b) argues that the new technology required weavers to acquire substantial new skills and few mill managers initially knew how to set up organizations to do this. Managers, furthermore, needed intimate knowledge of the technology. Zevin (1971: 145) points out that almost none of the mills survived during the early years unless they had their own machine shops or a close relationship with an outside shop. The machine shops themselves faced a limited supply of mechanics who knew how to build and install this new equipment. As late as 1845, the Locks and Canals Company experienced production delays caused by skilled labor shortages, thanks to a scarcity of mechanics and the long training and experience needed (Gibb, 1950).

One sign of the critical role of managers and mechanics is that some of them held equity stakes in the new mill companies. For example, both Paul Moody, the mechanic, and Kirk Boott, the mill agent (manager), were shareholders in the Merrimack Company, which built the first weaving mill at Lowell.

\subsubsection{Profits and innovation}

During the first two decades, the mills were able to earn high profits because they could produce at lower unit cost than handloom weavers or British imports, after taking the effect of tariffs into account. Similarly, given the shortage of mechanics, machine shops also earned supra-normal profits. Margins declined gradually during the period of coexistence:

In the years immediately before and after 1820 the Boston Manufacturing Company sold machinery at average prices 50 per cent above direct costs. By 1830 the successor, Locks and Canals Company, contracted to make machinery for a 30 to 35 per cent advance above costs. By the late 1830s, it contracted to build the Massachusetts Cotton Mills for a profit of 5 to 10 per cent on direct costs (Zevin, 1971: 144).

Margins were high for two decades. But Gibb (1950: 78) notes that during the 1830s, Locks and Canals began the practice of frequently licensing improvements made by other manufacturers, implying that "no longer could a machine shop, however large, enjoy unchallenged local demand for all its products." By the mid-1830s, competition from outsiders had finally become significant.

Zevin (1971: 143) notes a similar or perhaps even slower decline in gross cloth margins, from 5.33 cents per yard in $1823-1828$ to 3.85 cents per yard in $1834-1843$, to 2.72 cents per yard in 1859-1860 for coarse cloth at the Blackstone Manufacturing Company. ${ }^{17}$ Both the mills and the machine shops earned high profit margins while the new technology coexisted with the old; margins were smaller when the old technology had been replaced.

On the other hand, there were well-known benefits to exchanging knowledge. Mechanics of this era widely shared knowledge with others in their networks (Wallace, 1978; Meyer, 2006; Thomson, 2009). They generally visited each other's shops, learning from each other's techniques and shared inventions, sometimes even at an early stage. ${ }^{18}$ Textile

17 These estimates are calculated these from the figures in his Table 3. These differ slightly from the averages reported in Zevin's text.

18 Wallace (1978: 216) writes, "They visited each other's shop constantly to exchange information, to stand silently watching a new machine or a new process, to speculate about the future of the mechanism. By and large, they knew each other's business and did not hesitate to show each other inventions in embryo, trusting their peers to honor their priority and the economic advantage it might mean. Their patents were often not taken out until years after the invention had become widely known in the fraternity; patents once taken were sometimes not announced or enforced, the patentee trusting his customers to honor his interest without reminder. To be sure, there were patent-infringement suits, like those levied by the embittered Oliver Evans, yet many of these were directed not against fellow mechanicians but rather against exploitive manufacturers." 
technology was highly complex, and for each step in the process, there were many different ways of proceeding and many different techniques to build the equipment. No one machine shop on its own could expect to develop the best equipment in all areas and build it using the best techniques. The BMC developed the most complete product line, yet still actively sought to learn from others. For example, Francis Cabot Lowell, founder of BMC, proposed to the owner of another mill "that we might see your machinery and copy from it as far as we pleased provided we would permit you to have the use of our patent Looms and warping machine and permit you to copy our Dressing machine" (Gibb, 1950: 40).

This sort of knowledge exchange could apparently be highly beneficial, as suggested by the exceptionally strong productivity growth that accompanied it. ${ }^{19}$ The labor time required to weave a yard of standardized coarse cloth fell from about $39.6 \mathrm{~min}$ on the handloom to $8.3 \mathrm{~min}$ on power looms at the Lawrence Company by 1835 (Bessen, 2012a), a $79 \%$ reduction. The main inventions responsible for this reduction were either not patented or patents were not enforced. Only about $3 \mathrm{~min}$ of the 31.3-min reduction can be attributed to the patented loom temple. Even ignoring the initial power loom invention, which came substantially from England, the specifically American improvements in productivity were large during this period. From the BMC in 1819 to the Lawrence Company in 1835, the labor time required to produce a yard of cloth fell from $15.9 \mathrm{~min}$ to $8.3 \mathrm{~min}$, a $48 \%$ reduction (Bessen, 2012a). Whereas later inventions, such as the Northrop loom, generated substantial relative decreases in labor time, the greatest absolute reductions occurred during this period of free knowledge exchange.

Thus, knowledge exchange appeared to do little to dampen innovation incentives and may have done much to boost innovation itself. There was little downside from exchange thanks to the high rents that manufacturers earned.

\subsubsection{Role of patents}

Conversely, these conditions also meant that the mills had little to gain by using patents to exclude firms from the market. This is seen in the experience of the BMC, which began by patenting its inventions, but later reversed course. Francis Cabot Lowell of the BMC introduced the first commercially successful power loom in the United States, 2 years before Gilmour. Gilmour's design later proved superior, but for a brief period, the BMC loom was the leading technology. In contrast to Gilmour, Lowell and his agent Jackson patented their loom in 1815. Also, BMC's talented mechanic, Paul Moody, acquired eight additional patents on related equipment. In 1817, the BMC began offering patent licenses to its equipment designs, and it began manufacturing patent looms and other cotton textile equipment then as well (Gibb, 1950).

However, after a few years, the BMC reversed course. After 1821, Paul Moody did not obtain any more patents, despite making key innovations in such areas as power transmission within the mill (Burke, 1847; Gibb, 1950). These innovations were not patented but instead diffused rapidly through the industry, quickly becoming standard in all new mill construction. In 1823, the BMC ceased sales of equipment and patent licenses except to closely related companies (Gibb, 1950). That year, the machine shop was sold to a related company and the following year it was moved to East Chelmsford, where it began producing equipment for new mills owned by closely related firms in Lowell, Massachusetts. For the next two decades, the continuing machine shop operation only sold to outsiders occasionally.

Why did Boston Manufacturing give up on patents? Simply, because they could make more money putting the machine shop resources into building capacity for their own use. From 1817 through 1823, the BMC sold patent licenses on textile equipment worth $\$ 8354$ (Gibb, 1950). In addition, they made gross profits on sales of manufactured textile equipment of $\$ 33,190$, part of which can be considered patent rents. Thus, they did make money on their patents. However, during the same period, profits on their own production of cotton cloth were much larger. Dividend payouts during this same period totaled $\$ 718,000$ (on capital of $\$ 600,000$ ).

This large difference meant that the opportunity costs of devoting resources to patent licensing outweighed the profits on patents. To make the comparison more concrete, the one-time patent licensing fee on a single power loom was $\$ 15$; the profit on each loom they built was $\$ 35$. But each loom in cloth production earned profits of over $\$ 200$

19 Of course, exchange could take place through negotiated patent cross-licenses, but this sort of exchange is likely to be incomplete because of transaction costs and asymmetric information about the technologies. Free exchange did not have such obstacles. 
each year during the early $1820 \mathrm{~s}^{20}$ The one-time patent royalty on a loom was less than $1 \%$ of the present value of expected profits from the operation of a loom. Thus, it made far more sense to put the machine shop to work building equipment for BMC's own use or the use of closely related companies. It only made sense to build textile equipment for other mills, perhaps, during temporary lulls in expansion plans. This appears to be the policy that the BMC machine shop and its successor companies followed through the 1830s as they built the equipment for the mills of Lowell, Massachusetts. And, whereas BMC could have continued to make some money selling a small number of patent licenses, it turned out that what customers really needed were licenses to BMC's entire technology, including their technical know-how and unpatented technology. From 1817 through 1823, BMC sold a few such complete technology licenses, making three times the royalties they earned from pure patent licenses (Gibb, 1950: 47). But the market for "naked" patent licenses was limited because these licenses would have been of little value without close access to a knowledgeable, skilled machine shop. But there were few such machine shops and, besides, these shops would likely have access to other loom designs, further limiting the market. In any case, complete technology licenses diverted the resources of BMC's machine shop away from producing their own equipment, imposing an opportunity cost. ${ }^{21}$ Profits were still far greater making equipment for their own use, and so, the patent licensing program was dropped.

Nor was weakness of the patent system responsible for the relatively small magnitude of profits from patents. The BMC did have difficulty enforcing its patents for the double speeder (a machine used for winding cotton prior to spinning), in part because of faulty drafting of the patent (Jeremy, 1981). However, the power loom was the key invention, and it appears that the BMC had no difficulty getting $\$ 15$ per loom for a patent license or $\$ 35$ gross profit on manufactured looms through 1823 (Gibb, 1950: 47). ${ }^{22}$ Moreover, the patent royalty of $\$ 15$ compares reasonably well with the $\$ 25$ royalty that the powerful sewing machine patent pool was able to charge on a comparably priced piece of equipment (Lampe and Moser, 2010). ${ }^{23}$ Clearly, even if BMC had been able to charge a $\$ 25$ or even a $\$ 50$ royalty, the basic arithmetic still favored producing machines for their own use. Because the rents earned on technical knowledge were so much greater than the rents that could be earned on patents, under these conditions it made sense for mechanics and mill managers to exchange innovations.

Of course, patents were still valuable to independent inventors who did not necessarily possess the skills and experience to build equipment on a large scale and to manage production operations efficiently. Nevertheless, the same economics sometimes made it difficult for these inventors to capture much of the value of the technology. For example, Ira Draper was one of the more successful independent inventors during the 1820s and 1830s. He developed a successful loom temple, an attachment to the loom that kept the edges of the cloth straight. Draper patented this device in 1816 and he obtained a patent on an improved version in 1829 (Mass, 1989). In 1830, Draper's successor licensed the patent and also sold his own manufactured version for \$2. By comparison, the loom temple saved cloth manufacturers about $\$ 35$ each year on each loom in labor costs. ${ }^{24}$ Draper only captured a small part of the value of

20 The 1820 Census of Manufactures reports 1,350,000 yards of cloth produced on 175 looms at the mill in Waltham in 1819, or 7714 yard per loom per year. During the early 1820s, BMC made about 9 cents per yard in profit (Ware, 1931: 114). Assuming that one third of the profits earned on cloth production could be allocated to looms (looms comprised about one third of capital costs (Montgomery, 1840), the annual profit per loom would be $\$ 231$.

21 At least one of these licenses made claims on Moody's time when he was not occupied at Waltham (Gibb, 1950: 43).

22 The persistence of this royalty through 1823 supports Gibb's analysis that the BMC did not experience significant price competition from Rhode Island mechanics using other designs, including Gilmour's.

23 BMC's cost for building a loom was $\$ 90$; sewing machines cost about $\$ 75$.

24 The loom temple reduced the labor required per yard of cloth by about $3 \mathrm{~min}$ (Bessen, 2012a). A loom at the Lawrence Company in 1835 produced 14,465 yards per year (Bessen, 2012a), implying a savings of about 723 labor hours per loom per year. At a mean wage of 4.9 cents per hour (Layer, 1955), this comes to a savings of $\$ 35.44$ per year per loom. 
his invention because the textile manufacturers were in a strong bargaining position relative to independent inventors such as Draper. ${ }^{25}$

Consistent with the model, patents appear to have become more valuable when the old technology was completely replaced and the market became more competitive during the 1830s. The number of patents on looms that were granted each year increased sharply during the mid-1830s, and this was distinct from the general trend if increased patenting. A statistical test of grant rates for loom patents identifies 1833 as the year of a significant break, the same year that the industry stopped growing rapidly. ${ }^{26}$ Moreover, inventors could build market power by accumulating large numbers of patents. Draper's successors did just this, creating a pool of key patents on high-speed spindles in the 1870s and acquiring over 400 patents on their own on spindles between 1871 and 1903 (Mass, 1989). In 1895, when the Draper Company introduced the Northrop automatic loom, a major new weaving technology, they acquired a large portfolio of patents that gave them a dominant market position for decades (Mass, 1989). Clearly, patents played a very different role in 1895 than during the first two decades of power weaving.

\subsection{Bessemer steel}

\subsubsection{Coexistence}

Patents played a much more central role in the development of Bessemer steel, making this example an interesting contrast to power weaving. In 1855, Henry Bessemer patented a process in Britain for refining steel by blowing oxygen through the molten metal. This process promised much cheaper steel, produced much more rapidly. But at that time, the technology was not well understood and the first attempts at commercial production failed, mainly because of difficulties in controlling the amount of phosphorus and carbon in the steel. Robert Mushet patented a technique in 1856 for controlling the carbon content and after much experimentation and the acquisition of low-phosphorus pig iron from Sweden, Bessemer began commercial production in 1858 (McHugh, 1980).

Although the original technology was developed in England, US innovators turned a somewhat crude technology into a true mass production tool. The largest market for steel produced using the original Bessemer process turned out to be steel rails for the booming American railroads. This market benefited from dramatic additional improvements in the scale, speed, and cost of the technology realized by US innovators. By 1879, US production of Bessemer steel equaled and then exceeded British production (Bessemer, 1905: 340). Most of the US improvements were realized through the free exchange of knowledge among competing Bessemer steel mills.

Railroads initially used rails made of iron, but in 1862, rails made of Bessemer steel were first used in Britain (Bessemer, 1905). Although steel rails were initially much more expensive than iron rails, they lasted much longer and, for that reason, were economical when used on the most heavily traveled sections of track. Also in 1862, Alexander Holley visited Bessemer's British operation to learn about the process and with an eye to acquiring US rights to the technology (Bessemer, 1905). For his partners, Winslow and Griswold, Holley acquired rights to Bessemer's US patents in 1865, along with detailed plans for constructing a mill (Temin, 1964).

At roughly the same time, another group acquired rights to Robert Mushet's US patent and to a US patent of William Kelly that covered some features of the Bessemer process, although Kelly had not actually produced steel using this process (Gordon, 1992). This gave rise to a situation of blocking patents where one group controlled

25 First, because there were alternative loom temples already on the market, the effective value of Ira Draper's loom temple to a textile manufacturer was only its incremental value over the next best model. Second, bargaining was more akin to a bilateral monopoly bargaining game where the parties split the rents. This is different from a fully competitive market where each manufacturer has to have the lowest cost technology to remain profitable and so inventors have more bargaining power.

26 The "sup-Chow" test identifies this break as significant at the $1 \%$ level using the Quandt likelihood ratio test (Quandt, 1960) with an F-statistic of 14.58. The data from 1816 through 1846 come from Burke (1847); we count patents described as looms, bobbins, cloth manufacture, and weaving. After 1846, the patent counts come from the USPTO technology class database, dated December 2010. We include Class 139, "Textiles: weaving," excluding subclasses less than 35 (Miscellaneous, Pile tufting, special-type looms), greater than 380 (mainly Fabrics), and 318-335 (Pattern Mechanisms). Because the classifications are different for the two data sources, we adjusted the counts after 1846 by the ratio of total patents granted in each database for the years 1836-1846, when the two sources overlap. 
Bessemer's patents on the equipment while the other group controlled patents on the process. In 1866, the two groups formed a patent pool to settle the conflict, with a share of the rights going to Winslow and Griswold (but not Holley) and the Kelly patent group.

The pool offered licenses to third parties for a modest flat fee plus running royalty (Temin, 1964). ${ }^{27}$ Licensees received rights to the current patents plus rights to any future patents on steelmaking that the principles might obtain. But the license was also designed to encourage the transfer of knowledge (Temin, 1964). Licensees received plans for a plant and detailed information on the process. To help transfer know-how, licensees could train two people at the Troy, NY plant run by Winslow, Griswold, and Holley. And they were permitted to visit the Troy plant on an ongoing basis and were required to make their own plants open to the pool (McHugh, 1980).

In addition to the formal communication requirements contained in the license agreement, the mills established several practices that ensured a high level of knowledge exchange. The top five or six engineers from the various mills met frequently to discuss technical issues (Temin, 1964). ${ }^{28}$ One of the engineers, John Fritz, later wrote that "we met as a band of loving brothers... What each of us knew was common to all...This fraternal relationship was very important in the exchange of information in a new field" (Fritz, 1912: 160-161). Also, technical personnel rotated from one mill to another, learning the process under different conditions (Meyer, 2003). Usually, managers at the new mills had been trained at older mills. Also, from 1874 through 1877, Alexander Holley produced a series of 1520 technical reports for licensees (Temin, 1964: 134). More generally, professional associations and publications for iron and steel professionals and engineers facilitated knowledge exchange. Several of the key Bessemer plant engineers published in the Transactions of the American Institute of Mining Engineers (Meyer, 2003; for a full catalogue of Alexander Holley's papers and writings, see McHugh, 1980: 384-390).

In 1877, the existing Bessemer mills formed a new patent pool based on the remaining patents still in force, including 10 patents granted to Holley. The pool decided to restrict the use of these patents to mills currently making Bessemer steel and the pool ceased advertising for new members. Thus, 1877 marked both the end to the extensive knowledge sharing and also a new attitude to rivals, seeking to limit entry into the industry. ${ }^{29}$

It also more or less marked the end of coexistence with the alternative technologies. The alternatives were iron rail, which was inferior, and imported steel rail that was subject to a steep tariff. In 1867, US Bessemer steel accounted for a fraction of $1 \%$ of all rail produced or imported then. But by 1877 , the price of Bessemer rail was only $29 \%$ higher than the price of iron rail and, for the first time, US Bessemer steel accounted for over half of all rail $-57 \%$ of the total market. In that year, there were virtually no British imports. By 1884, US-produced steel rail cost less than iron rail and accounted for $97 \%$ of all rail.

\subsubsection{Constraint}

Why did not more firms enter during the first decade of the industry? One reason was uncertainty about how well the technology would be able to perform and the large size of the investment required to establish a new mill. But it also seems likely that talented engineers and managers familiar with Bessemer technology were also in limited supply at that time. As noted above, managers of the new works were usually trained on-the-job at the mills already operating (Temin, 1964: 133). Given the small number of operating mills during the early years, this could only have generated a supply rather slowly. Particularly, important were the talents and experience of Alexander Holley, who provided plans for six of the mills and consulted on two of the others. Indeed, the one mill that was not built to a Holley design quickly turned out to be inefficient and failed (Temin, 1964). McHugh (1980: 200) writes that Holley was "one of three or four men in America who had the ability to construct and operate a Bessemer plant."

As with some of the managers and mechanics of the cotton mills, these engineers were particularly well-paid, in some cases receiving a share of the production. Holley was initially one of three people with rights to the Bessemer patents in the United States, but he was not one of the principal owners of the pool. The formation of the pool

27 The flat fee was $\$ 5000$ compared with an initial mill cost of $\$ 80,000-\$ 200,000(2.5 \%-6 \%)$. The running royalty was equivalent to about $\$ 5$ per ton of steel at a time when the price of steel was initially $\$ 166$ per ton, making the royalty $3 \%$; the price fell to $\$ 106.75$ by 1870 , making the royalty roughly $5 \%$ (Temin, 1964).

28 This included Alexander Holley, John Fritz of Bethlehem Iron Company, where the meetings were often held, George Fritz of Cambria Iron, R. W. Hunt from the Troy works, and William Jones of the Edgar Thomson Works.

29 In 1875, the patent pool had attempted to limit production to prearranged quotas for each mill, but this effort at a cartel collapsed. 
involved financial negotiations that apparently relieved some of his debts, but the details are not known (Temin, 1964: 128-30). In addition, Holley was paid well for his consulting activities. His consulting contract for building the Edgar Thompson works included a \$5000 fee plus \$2500 annual payment (Bennett, 1995). Others of the engineers grew wealthy. John Fritz of the Bethlehem Iron Company left money to a variety of charitable institutions, including \$150,000 to Lehigh University. William R. Jones, general superintendent of Edgar Thompson mill, asked for and received "a hell of a big salary" from Andrew Carnegie. He was paid \$25,000 per year plus a percentage on the product of the mill, coming to almost $\$ 50,000$ a year. Carnegie offered Jones an equity stake, but he turned it down (Carnegie, 1920: 203). The pay of these engineers is indicative of the rare value of their knowledge and skills.

\subsubsection{Profits and innovation}

During the first decade of Bessemer steel production in the United States, the production of these mills had little effect on the price of steel rails because it was only a small part of the total production of rails. Prices were initially set to fall just below the price of British steel rail imports after taking into account tariff and transportation costs (Morison, 1966: 171-172).

Although profit data are fragmentary, this pricing created opportunity for substantial profit margins. ${ }^{30}$ It took the first mills several years to become fully productive. The Pennsylvania Steel Company began production in 1867 with barely over 1000 tons produced (Morison, 1966: 168-169). It did not pay a dividend until 1873. But in 1878, it produced nearly 84,000 tons and made profits of nearly $80 \%$ of total capitalization, a profit margin on sales of about $45 \%$. The Edgar Thomson Steel Works had a profit rate of $20 \%-30 \%$ of capital during its first 3 full years of operation, from 1876 to 1878, years of depressed demand (Temin, 1964). But during the boom year of 1881, the Edgar Thomson Works earned a return of $130 \%$ of invested capital.

The profit opportunities and the knowledge sharing apparently helped achieve remarkable technical progress, as shown in the dramatic reduction in the cost of production. The price of Bessemer steel rail minus the cost of pig iron (the primary input) fell from $\$ 122$ in 1867 to $\$ 27$ in 1877 (Temin, 1964), a reduction of $78 \%$. Further progress was made after 1877 , but clearly most of the productivity gain was realized during this first decade. These advances allowed the US industry to produce the large quantity of rail needed by the booming railroads and to do so at prices less than could be offered by British producers.

\subsubsection{Role of patents}

In the case of Bessemer steel, patents clearly played a much more central role than they did with the power loom in the United Staes. The pool was formed to prevent litigation over blocking patents. Moreover, Bessemer's original invention was a highly successful example of the rewards that patents could provide. Jeans wrote in 1884 that Bessemer had earned "the largest fortune perhaps that has ever been reaped from a single invention."

Nevertheless, the inventors of the original patents earned little in the United States relative to the profits earned from operation of the steel mills, much as was the case with power weaving. A major reason for this was that it took so long to make the process commercially viable. Consequently, patents largely expired before production ramped up in the United States. ${ }^{31}$ The Bessemer and Mushet patents expired in 1870. The Kelly patent expired in 1871, but Kelly successfully petitioned for an extension through 1878. In his petition, Kelly declared that he had only received $\$ 2400$ through 1871 (Temin, 1964: 176, fn. 15). Kelly is reported to have earned about $\$ 25,000$ more in royalties

30 In addition, the patent pool held joint price discussions with the railroads and railroads held interests in the steel companies (Morison: 173, Temin, 1964). However, based on Temin's analysis of subsequent developments (see below), it seems likely that any collusion would have had little effectiveness.

31 Bessemer's profits largely came from Britain, where 52 converters were producing steel by 1866, including his own Sheffield works (Jeans, 1880: 86). Steelmakers were able to avoid paying royalties in many other countries (McHugh: 208-209, fn. 27). 
during the patent extension. ${ }^{32}$ In our interpretation, these difficulties in exploiting the patents provide indirect evidence on the existence of forceful capacity constraints.

We can estimate an upper bound on the royalties from the original patents. Through 1870, the patent pool itself charged licensees \$5 per ton on steel for rails (Holley, 1866) and only 47,000 tons were produced through 1870 . Considering that the pool might have kept some of these royalties itself, the inventors could not have received more than $\$ 260,000$ in total, including Kelly's royalties after 1871. A single mill made greater profits than this in a single year. ${ }^{33}$ Put another way, if we assume that the mills earned an average profit margin of $10 \%$ on sales through 1877-the Edgar Thomson Works earned this much in 1876, a depression year ${ }^{34}$-then the payments on the original patents were less than $3 \%$ of total profits through $1877 .{ }^{35}$

This number would surely have been larger had Bessemer's patent (and Mushet's) been extended. Nevertheless, the value of the original invention itself was small without the additional knowledge needed to make the technology work efficiently at a large scale. These patents served to restrict the use of the Bessemer process to members of the pool, but admission to the pool was not costly and knowledge sharing within the pool served to make the process much more valuable.

After the original patents expired, the pool's subsequent patents proved to have only a limited ability to restrict entry. In Temin's analysis, these additional patents only restricted entry to a limited degree at most. ${ }^{36}$ Instead, the industry soon embarked on a consolidation spree, culminating in the formation of U.S. Steel. In contrast to textile technology, patents did not, apparently become particularly more valuable after the period of coexistence ended, but the desire to achieve market power was significant in both cases.

\subsection{Cornish mining and Cornish engines}

\subsubsection{Coexistence}

In the first half of the nineteenth century, Cornwall was one of the most advanced locations of the world in steam engineering. Remarkably, in Cornwall, inventive activities were mainly undertaken outside the coverage patent protection. In Cornwall, steam engines were used to pump water out of copper and tin mines. As coal in Cornwall was relatively expensive, the Cornish mining district had been one of the early adopters of Boulton and Watt engines that represented the best practice of the time in terms of fuel efficiency. Significantly, Watt patented his design for an engine with a separate steam condenser with a very broad specification. After Boulton and Watt's penetration in the Cornish market, several engineers began to develop further improvements, but were frustrated by Boulton and Watt's tight enforcement of Watt's patent (Nuvolari and Verspagen, 2007). The ultimate outcome was a period of stagnation in fuel efficiency.

In the wake of this disappointing experience, Cornish steam engineers typically preferred not to patent their inventions after Watt's patent expired in 1800. Accordingly, the share of Cornish patents in steam engineering for

32 Reported by Rossiter (1896), the secretary of the American Institute of Mining Engineers. Casson (1907) contends instead that Kelly received $\$ 30,000$ through 1870 and $\$ 450,000$ during the extended term. However, this claim appears without citation in his book, The Romance of Steel: The Story of a Thousand Millionaires, which is dedicated to demonstrating the wealth generated by the new technology. Casson's claim appears to be dramatically at odds with Kelly's submission to the Commissioner of Patents.

33 The Edgar Thomson Steel Works, albeit one of the better-managed mills, made profits of $\$ 181,000$ in $1876, \$ 190,000$ in 1877 , and $\$ 402,000$ in 1878 , all relatively depressed years. During the boom year of 1881 , the mill made profits of $\$ 1.625$ million (Temin, 1964: 172).

34 In 1876, its first complete year of operation, the Edgar Thomson Steel Works produced 32,000 tons of rail (Bennett 1995: 15). Given a market price of $\$ 59.25$ per ton (Temin, 1964) and profits of $\$ 181,000$ (Temin, 1964: 172), a net margin of $9.5 \%$ was yielded.

35 Sales of steel rail were over $\$ 100$ million through 1877 , as estimated by multiplying the average price in Pennsylvania by total production for each year from Temin (1964).

36 "Restriction of entry by means of patents helped the existing steel firms to exploit the boom of 1879-1882 and it helped refuse entry to at least one new firm in the following years. Several other new firms were successful, however, and we may conclude that the use of Holley's patents for restrictive purposes was not very important for the industry as a whole. In any case, these patents expired in 1886, and entry was free as far as patent costs went." (Temin, 1964: 182). 

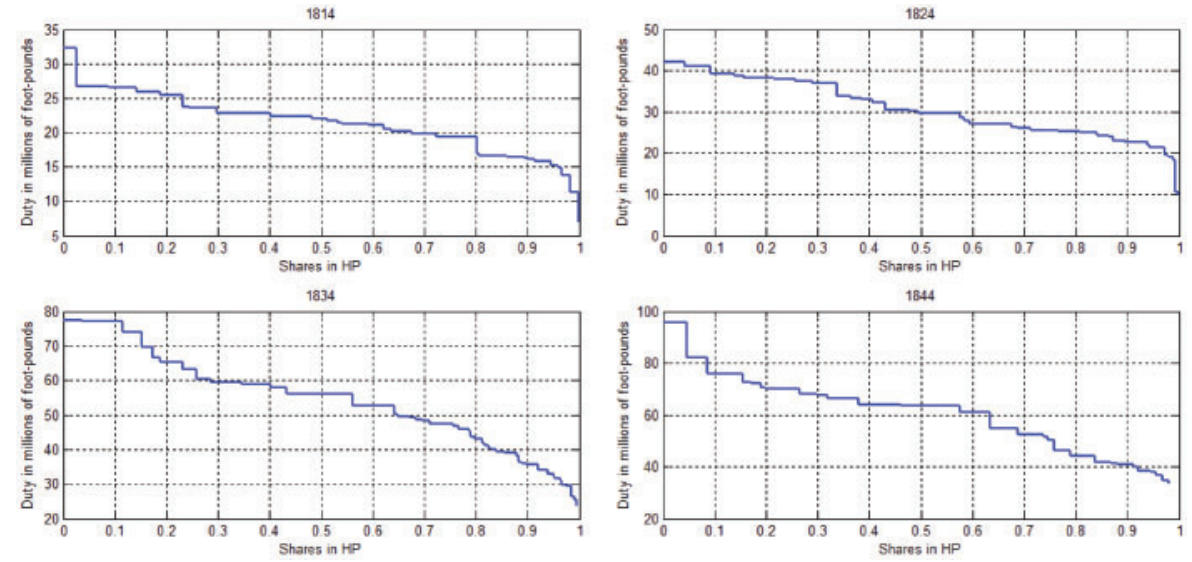

Figure 2. The distribution of duty of Cornish engines (1814, 1824, 1834, and 1844).

Source: Lean's Engine Reporter (April, various issues)

the period 1813-1852 fell to under 1\% of the national total (Nuvolari, 2004: 358). Furthermore, in 1811, Cornish mining engineers and entrepreneurs launched a monthly publication containing detailed reports on the performance, technical details, and operating procedures of the steam engines at work in the county. The explicit intention was twofold. First, the publication would permit the rapid identification and diffusion of best-practice techniques. Second, it would create a climate of competition and emulation in the Cornish engineering community with favorable effects on the rate of technical progress. Joel Lean, a highly respected mine "captain" was entrusted with the compilation of the reports and the publication was known as Lean's Engine Reporter. It is exactly after the publication of Lean's Engine Reporter that Cornwall attained the world technological leadership in steam engineering with the introduction of a particularly successful high-pressure condensing engine that would become known as the "Cornish" engine (Barton, 1969). ${ }^{37}$ The systematic comparison of technical features, operational procedures, and performance of the engines allowed engineers to identify the best design configurations, for example in terms of cylinder size, for attaining economies of fuel (Nuvolari and Verspagen, 2009).

Concomitant with the beginning of the publication of Lean's Engine Reporter, Richard Trevithick and Arthur Woolf installed high-pressure engines in Cornish mines. The layout of the engine designed in 1812 by Richard Trevithick at the Wheal Prosper mine soon became the basic one for Cornish pumping engines. Interestingly enough, Trevithick did not patent this high-pressure engine. ${ }^{38}$

In the Cornish engine case, it is possible to point to a co-existence between technology at two levels. First, during the period of knowledge sharing, total mining costs for tin and copper were well below the world prices, suggesting that Cornish mining technology co-existed with alternatives in the world. Second, it is also possible to identify a coexistence between technologies inside the Cornish mining district. Nuvolari and Verspagen (2009: 695-696) have

37 Notably, even though specific inventions introduced in Cornwall can be ascribed to individual inventors (e.g., the tubular boiler to Richard Trevithick, the compound engine design and the double beat valve to Arthur Woolf), the high-pressure condensing engine would become known as the "Cornish" engine, giving credit to the whole community of engineers.

38 In fact, Trevithick had an ambiguous attitude toward patents (arising from an unsolved tension between appropriation and desire of the widest possible dissemination of his discoveries). Although he did not patent the Wheal Prosper design, he took five patents for other inventions in steam technology. It must also be noted that Trevithick's travel in South America in the topical period 1816-1827 prevented him from controlling the adoption of his inventions, leaving free ground to imitators and improvers. Another famous contemporary mining invention not patented was the miner's safety lamp contrived by Humphry Davy (another famous Cornishman) in 1815. Davy explicitly refused to take a patent for his invention to ensure its wide and quick diffusion, see Knight (1992: 112). 
Table 2. Production of fine copper in Cornwall, 1801-1881

\begin{tabular}{|c|c|c|c|}
\hline Period & Cornish production in tons & $\%$ share of UK production & $\%$ share of world production \\
\hline 1801-1810 & 60,597 & 93.226 & 66.590 \\
\hline $1811-1820$ & 67,030 & 91.822 & 69.823 \\
\hline $1821-1830$ & 91,295 & 86.127 & 67.626 \\
\hline $1831-1840$ & 116,161 & 81.231 & 53.285 \\
\hline $1841-1850$ & 115,499 & 83.695 & 39.690 \\
\hline $1851-1860$ & 121,458 & 85.534 & 24.004 \\
\hline $1861-1870$ & 90,614 & 78.116 & 10.068 \\
\hline $1871-1880$ & 36,244 & 77.115 & 3.047 \\
\hline
\end{tabular}

Source: Rowe (1953: 128).

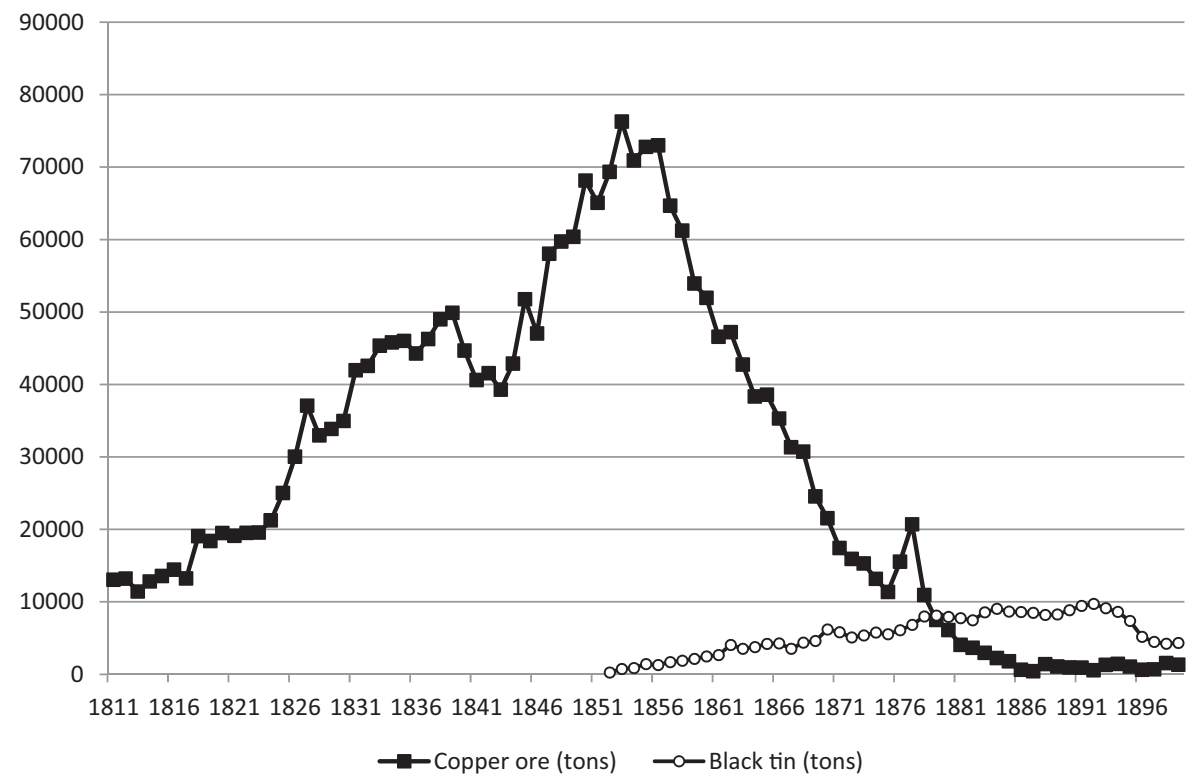

Figure 3. Production of the Camborne-Redruth mines (1811-1895).

Source: Morison (1980: 373-375)

shown that the large bulk of technological innovations was "embodied" in the installation of new productive capacity (installation of new engines). Using the data of Lean's Engine Reporter, it is possible to represent the distribution of the fuel efficiency ("duty") of the engines installed using "Salter" type of diagrams (Figure 2).

In Figure 2, the capacity of engine is computed as the number of horsepower (HP) delivered. The duty of the engine is reported on the vertical axis, and its share in the total number of horsepower (HP) delivered by the engine park of the mining district is reported on the horizontal axis. The diagrams of Figure 2 are very similar to those presented by Salter to discuss the diffusion of innovations and clearly point to the co-existence of different vintages of the technology (Salter, 1960: 53). This co-existence is, by and large, explained by the "embodied" nature of technical change in the case in question. In a detailed study of the performance of Cornish engines, Nuvolari and Verspagen (2007) argue that the history of the Cornish engine may be usefully interpreted in terms of three major waves of "embodied" technological change. 


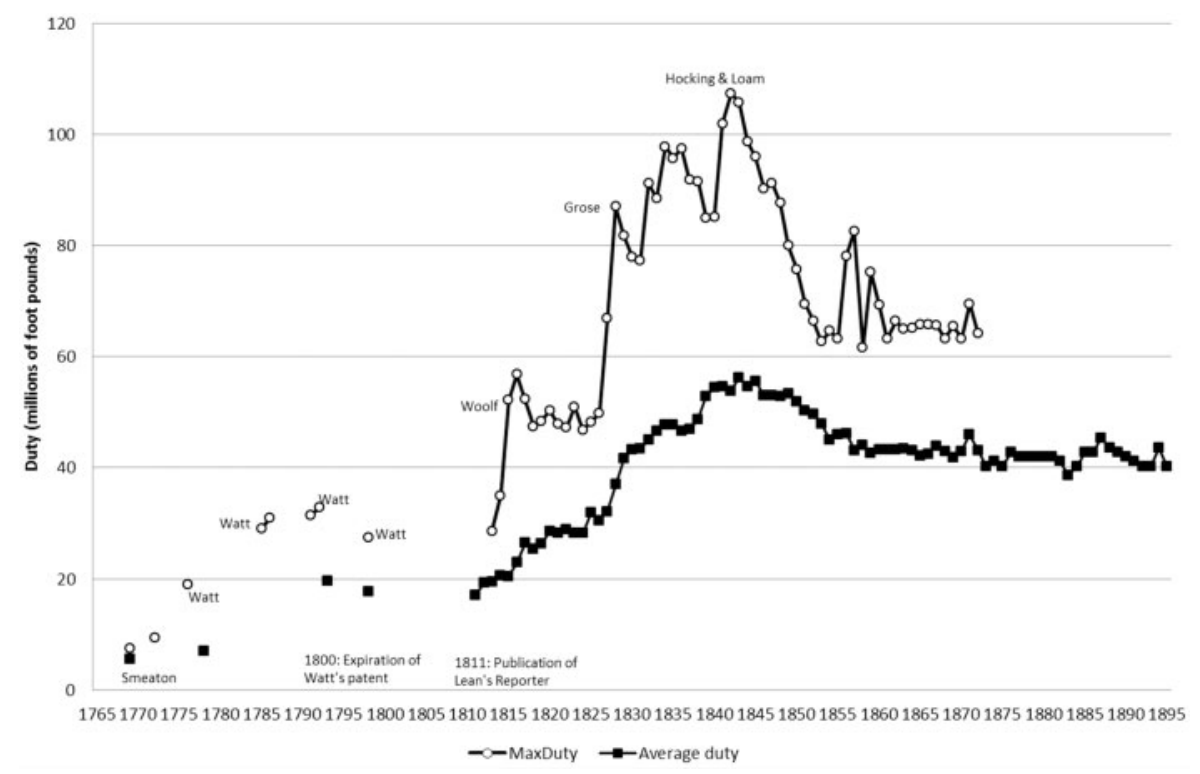

Figure 4. Duty of Cornish engines, 1769-1895.

Source: Nuvolari and Verspagen (2007: 171)

\subsubsection{Constraint}

Besides the constraint represented by the embodied nature of technical change, which prevented the systematic retrofitting of innovations on already installed capacity, the scale of Cornish mining and the concomitant use of the Cornish engine were limited by the number and size of useful mining sites. Cornwall's copper and tin deposits were unusual in that the seams were vertical, which required the use of engines. But the limited number of sites, although deposits were often rich, meant that Cornish mining coexisted with other mining techniques used elsewhere. New deposits open to less costly mining techniques eventually emerged elsewhere, undercutting the Cornish industry, effectively ending the effectiveness of the constraint. Table 2 shows the historical evolution of share of copper production, respectively, on the total of UK and the total world share over the period 1801-1880.

Figure 3 shows the production of copper and tin ore of the Camborne-Redruth district. As far as copper production is concerned, the district was characterized by a continuous increase until the mid-1850s. After this peak, the copper mining industry exhibits a prolonged phase of the decline.

Another constraint was represented by the pool of engineers that could design and install high-pressure engines. Cornish pumping engines were designed by independent consulting engineers, who typically provided their services to different mines for an annual fee. The tasks of the engineer were to provide the drawings of the engine (including the engine house) to the selected foundry ${ }^{39}$ and to the other manufacturers involved in the construction of the various components, to supervise the installation of the engine, and to pay occasional visits to the mine to give directions concerning the operation and maintenance of the engine (once this was installed). The profession of engineer was typically a family vocation, with sons usually learning the "secrets of the trade" from their fathers. ${ }^{40}$

In Cornwall, the early use of steam power during the eighteenth century had resulted in the formation of a community of steam engineers. However, the expansion of copper mining from the 1810s put this community under stretch, in particular because the high-pressure engines required higher engineering standards than the Newcomen and Watt engines. Harris (1966) notices that Arthur Woolf was a key figure in the process of education and

39 "With the sole exception of Woolf, who was connected with Harvey \& Co. as founders, the Cornish engineers appear to have been quite independent of any particular foundry, a system that undoubtedly assisted the free development of the Cornish engine and engineering during their heyday" (Barton, 1969: 147-148).

Useful biographical information on a number of Cornish engineers is provided in Harris (1977). 
Table 3. Profitability of some Cornish mines (1811-1895)

\begin{tabular}{lcrrr}
\hline Mine & Year-engine (reported, 1811-1876) & Investments $(£)$ & Dividends $(£)$ & Return per $£$ invested \\
\hline Dolcoath & 90 & 45,238 & 904,641 & 19.997 \\
Carn Brea & 35 & 134,525 & 392,500 & 2.918 \\
Cook's Kitchen & 27 & 175,379 & 28,582 & 0.163 \\
South Wheal Frances & 26 & 80,888 & 203,164 & 2.512 \\
North Roskear & 24 & 50,700 & 58,800 & 1.160 \\
Tincroft & 23 & 92250 & 348,900 & 3.782 \\
Wheal Basset & 19 & 78,298 & 341,709 & 4.364 \\
\hline
\end{tabular}

Own computation based on Morrison (1980).

apprenticeship to the higher engineering standards required by the use of high-pressure steam of many Cornish engineers of the nineteenth century.

Finally, another constraint on the expansion of capacity was represented by the availability of foundries that could manufacture the components of the engines (in particular the cylinders). Until 1810, these components were typically manufactured outside Cornwall. From the 1810, also thanks to the consultancy of Arthur Woolf, Harvey \& Co entered successfully in the business of making engine components (Barton, 1969: 149-150). The proximity of engineers and foundries led to a major improvement of engineering standards. Following the success of Harvey, other entrepreneurs entered in the business of engine-building in Cornwall, further relaxing this constraint on capacity (Barton, 1969).

\subsubsection{Profits and innovation}

Extensive sharing of knowledge among the mines did not, apparently, dissipate all rents. Some of the mines were fabulously profitable. The Tresavean mine earned its investors a 2000\% return on investment in the year of 1833 alone (Spargo, 1865: 99). Although profit margin data are fragmentary, what is available suggests that mines earned high margins for sustained periods, consistent with the model. The Dolcoath mine earned a profit margin of $32 \%$ in 1805; Penstruthal and Tresavean earned margins averaging $25 \%$ over 25 years; the Providence mine earned $44 \%$ from 1848 through 1864.

Knowledge sharing did not destroy the rents, and it appears to have helped rather than hurt innovation. As a result of the publication of the engine reports, the thermodynamic efficiency of Cornish engines improved steadily. On strictly engineering grounds, this amounted to a very effective exploration of the merits of the use of high-pressure steam used expansively.

Figure 4 displays the evolution over time of the efficiency of Cornish steam engines (based on the collation of several sources). The figure clearly indicates that the practice of information sharing was coupled with a marked acceleration in the rate of technical advance (measured in terms of "duty," millions of lbs of water lifted one foot high by the consumption of a bushel of coal).

Systematic collection and analysis of performance data published in Lean's Engine Reporter allowed to Cornish engineers to individuate a set of design principles that could successfully be used to project efficient steam engines, even in the absence of full-fledged theory of the functioning of the steam engine. By pooling together all the accumulated experience, it was possible to gain a deeper understanding of the connections between specific designs features and engine performance and, consequently, focus the search process in the most promising directions.

Existing records permit some back of envelope calculations of the profitability of some Cornish mines (Table 3). In the table we have also reported the intensity with which the mines in question published the performance of their pumping engines on the Lean's Engine Reporter. This is done in the second column using as measure the total number of engines-year reported ( 1 engine-year means that the mine in question published the performance of an engine in a given year). It is interesting to note also that mines that intensively reported their engines, such as Dolcoath, were able to gain very high rates of profit. 
Table 4. Geographical distribution of British steam engine patents, 1698-1852

\begin{tabular}{|c|c|c|c|c|c|c|}
\hline County & $\begin{array}{l}\text { No. of patents } \\
1698-1852\end{array}$ & $\begin{array}{c}\% \\
1698-1852\end{array}$ & $\begin{array}{l}\text { No. of patents } \\
1698-1812\end{array}$ & $\begin{array}{c}\% \\
1698-1812\end{array}$ & $\begin{array}{l}\text { No. of patents } \\
1813-1852\end{array}$ & $\begin{array}{c}\% \\
1813-1852\end{array}$ \\
\hline Cheshire & 14 & 1.23 & 0 & 0.00 & 14 & 1.39 \\
\hline Cornwall & 17 & 1.50 & 8 & 6.25 & 9 & 0.89 \\
\hline Cornwall $^{\mathrm{a}}$ & 21 & 1.85 & 12 & 9.38 & 9 & 0.89 \\
\hline Derby & 11 & 0.97 & 1 & 0.78 & 10 & 0.99 \\
\hline Durham & 13 & 1.15 & 0 & 0.00 & 13 & 1.29 \\
\hline Essex & 6 & 0.53 & 0 & 0.00 & 6 & 0.60 \\
\hline France & 21 & 1.85 & 0 & 0.00 & 21 & 2.09 \\
\hline Gloucester & 20 & 1.76 & 8 & 6.25 & 12 & 1.19 \\
\hline Bristol & 12 & 1.06 & 4 & 3.13 & 8 & 0.79 \\
\hline Hampshire & 9 & 0.79 & 0 & 0.00 & 9 & 0.89 \\
\hline Ireland & 13 & 1.15 & 1 & 0.78 & 12 & 1.19 \\
\hline Kent & 31 & 2.73 & 1 & 0.78 & 30 & 2.98 \\
\hline Lancashire & 145 & 12.78 & 5 & 3.91 & 140 & 13.90 \\
\hline Liverpool & 35 & 3.08 & 1 & 0.78 & 34 & 3.38 \\
\hline Manchester & 58 & 5.11 & 2 & 1.56 & 56 & 5.56 \\
\hline London \& Middlesex & 395 & 34.80 & 40 & 31.25 & 355 & 35.25 \\
\hline Northumberland & 22 & 1.94 & 2 & 1.56 & 20 & 1.99 \\
\hline Newcastle-up.-Tyne & 11 & 0.97 & 1 & 0.78 & 10 & 0.99 \\
\hline Nottingham & 13 & 1.15 & 1 & 0.78 & 12 & 1.19 \\
\hline Scotland & 47 & 4.14 & 6 & 4.69 & 41 & 4.07 \\
\hline Edinburgh & 9 & 0.79 & 0 & 0.00 & 9 & 0.89 \\
\hline Glasgow & 22 & 1.94 & 3 & 2.34 & 22 & 2.18 \\
\hline Shropshire & 6 & 0.53 & 3 & 2.34 & 3 & 0.30 \\
\hline Somerset & 4 & 0.35 & 2 & 1.56 & 2 & 0.20 \\
\hline Bath & 2 & 0.18 & 1 & 0.78 & 1 & 0.10 \\
\hline Stafford & 27 & 2.38 & 5 & 3.91 & 22 & 2.18 \\
\hline Suffolk & 5 & 0.44 & 0 & 0.00 & 5 & 0.50 \\
\hline Surrey & 88 & 7.75 & 10 & 7.81 & 78 & 7.75 \\
\hline United States & 13 & 1.15 & 2 & 1.56 & 11 & 1.09 \\
\hline Wales & 12 & 1.06 & 1 & 0.78 & 11 & 1.09 \\
\hline Warwick & 58 & 5.11 & 8 & 6.25 & 50 & 4.97 \\
\hline Birmingham & 55 & 4.85 & 6 & 4.69 & 49 & 4.87 \\
\hline Worcester & 11 & 0.97 & 1 & 0.78 & 10 & 0.99 \\
\hline York & 63 & 5.55 & 11 & 8.59 & 52 & 5.16 \\
\hline Bradford & 11 & 0.97 & 0 & 0.00 & 11 & 1.09 \\
\hline Kingston-up.-Hull & 9 & 0.79 & 2 & 1.56 & 7 & 0.70 \\
\hline Leeds & 17 & 1.50 & 3 & 2.34 & 14 & 1.39 \\
\hline Sheffield & 6 & 0.53 & 0 & 0.00 & 6 & 0.60 \\
\hline Others & 71 & 6.26 & 12 & 9.38 & 70 & 6.95 \\
\hline Total & 1135 & 100 & 128 & 100 & 1007 & 100 \\
\hline
\end{tabular}

${ }^{a}$ Cornwall including the patents taken by Arthur Woolf.

Source: Nuvolari (2004: 358).

\subsubsection{Patents}

Table 4 reports the geographical distribution (measured using the stated addresses of the patentees) of patents in steam power technology over the period 1698-1852 (see Andrew et al., 2000, for a detailed quantitative analysis of the pattern of steam power patenting over the entire nineteenth century).

Over the entire period 1698-1852, the share of Cornwall in total patenting is 1.85\%, which does not reflect at all the major contribution of the county to the development of steam power technology. Breaking down the period 1698-1852 into two subperiods (1698-1812 and 1813-1852) to take into account the publication of Lean's Engine 
Reporter is even more revealing. In the first period, Cornwall (including in the count also the patents taken out by Arthur Woolf who, at the time, was working for the Meux \& Reid brewery in London) is the county with highest number of patents after the London and Middlesex area, with a share of $9.38 \%$. In the second period, the share of Cornwall drops to a negligible $0.89 \%$, and this is exactly the period during which the Cornish pumping engine was actually developed. In our view, this finding is indicative of the widely perceived awareness in the county of the benefits stemming from the adoption of a collective invention regime for the rate of innovation. After the unfortunate experience with the Boulton and Watt monopoly, it seems quite clear that in the Cornish engineering community, an ethos prescribing the full release of technical innovations into the public domain emerged and became progressively established.

The case of Arthur Woolf is particularly illustrative. Woolf was one of the leading figures in the Cornish engineering community (Jenkins, 1932; Harris, 1966). Born in Cornwall, he had an initial apprenticeship with steam engineering by working with Jonathan Hornblower. In the first decade of nineteenth century he moved to London, where he was entrusted with the steam engines of the Meux \& Reid brewery. In this period, Woolf took out four patents for innovations in steam engines (in particular his famous compound engine patented in 1804). In 1812, he moved back to Cornwall, where he tried to commercialize his compound engine by means of an agreement similar to the one proposed by Boulton \& Watt (royalties paid as a proportion of fuel savings). His initiative was unsuccessful. Most mine adventurers awaited the expiration of the patent in 1818 before installing this type of engine (Nuvolari and Verspagen, 2007). ${ }^{41}$ Later on, in 1823, Woolf invented a new valve for steam engines (the double-beat valve). The adoption of this type of valve greatly facilitated the operation of the engine (Hills, 1989: 109-110). He did not claim any patent right for this invention. In the same period, he also introduced notable improvements in the cataract regulator, which he did not patent (Pole, 1844: 89). Similarly, Samuel Grose did not patent the system of thermal lagging that he introduced in 1826, even when Davies Gilbert had advised him to do so (Todd, 1967: 101).

Another example that confirms the negative attitude toward patents existing in the Cornish mining district is the limited diffusion of the two-cylinder compound engine patented by the Cornish engineer, James Sims, in 1841. The first engine of this type erected at the Carn Brea mine performed particularly well in terms of duty (it was the second best engine in the Reporter in the early 1840s). However, being a patented design made the engine quite unpopular with other engineers and mine-owners, who, in the end, preferred not to adopt it (Barton, 1969: 110-112).

One can point to other Cornish inventions in steam technology that were not patented. The "Cornish water gauge", an instrument that allows a prompt check of the height of water in the boiler, invented by Richard Hosking in 1833 , is a noteworthy case. In his Treatise, Pole describes it as "a very ingenious apparatus. . .almost unknown out of the county" (Pole, 1844: 109). The invention was awarded a prize by the Royal Cornwall Polytechnic Society and a detailed description was published in the Society's Reports. In fact, since its foundation, the Royal Cornwall Polytechnic Society, a local learned society, in 1833 awarded a yearly prize for "Inventions and Workmanship." A perusal of the yearly reports Reports of the society reveals that many inventions related to steam engineering. For the period 1833-1841, none of them was patented. It is also interesting to note that leading mine entrepreneurs, such as John Taylor, tried to steer the direction of inventive efforts by instituting prizes for inventions aimed at specific purposes (such as water meters for boilers and stroke counters). Overall, it is hard to tell the technological significance of these inventions. Remarkably, William Pole found some of them worthy to deserve a description in his Treatise, which indicates that they probably were not of trifling importance (Pole, 1844: 122).

\subsection{Summary}

The findings from the case studies are summarized in Table 1. In each case, knowledge sharing occurred while the new technology coexisted with inferior alternatives. The constraint at work in the first two cases was specific technical knowledge of managers, mechanics, and engineers. In Cornwall, a more long-lasting constraint was the limited number of mines where the technology was applicable. In the textile and steel examples, coexistence ended because the supply of knowledgeable specialists eventually grew. When coexistence ended and the new technology dominated

41 This was also the fate of the circular calciner (which is considered an important step in the mechanization of the ore dressing processes) patented by William Brunton: "Although the advantages of the calciner were evident, very few mines used it until the patent had expired, and then it was found in operation throughout the length and breadth of the county" (Ferguson, 1873: 147, remark made by T. S. Bolitho in the discussion of the article). 
the market in these cases, so, too, did most free sharing of knowledge. Firms continued to freely exchange some knowledge, for example, at industry trade associations, but not to the extent of earlier knowledge exchange. During all three episodes, firms made large profits and substantial technical improvements, suggesting that innovation incentives were not dampened, but were, if anything, enhanced. On the other hand, during the periods when knowledge was shared, patents provided relatively little economic incentive. In short, the coexistence model is consistent with the behavior observed in the case studies during the periods where knowledge was freely shared.

\section{Conclusion}

In the case studies, knowledge sharing did not dissipate rents because the new technology coexisted with inferior alternatives. Yet the diffusion literature shows that such coexistence occurs frequently during the early stages of new technologies. Thus, the coexistence model provides a simple explanation as to why knowledge sharing appears with some frequency.

Moreover, because coexistence is typically temporary-it ends when the critical constraints on the new technology ease, which Rosenberg (1976: 189-210) originally pointed outb—the model also explains why these episodes are often temporary. The implication is that standard models of rent dissipation do not apply universally, although they might typically apply in the long run. But as the case studies show, the early stages of new technologies can achieve critical technological advances in a knowledge-sharing regime.

This richer picture might help explain a puzzle about the role of patents during the Industrial Revolution. Since North (1981), institutional economists have argued that stronger property rights were an essential precondition to the Industrial Revolution. Yet scholars studying the role of patents during the Industrial Revolution have had difficulty finding a central role for patent incentives in instigating inventive activities (MacLeod, 1988, Mokyr, 2009: 403-410). Many of the major inventors of the early Industrial Revolution did not benefit from patents, either because they failed to obtain them, the patents were invalidated, or the inventors could not successfully enforce and profit from their patents (Mokyr 1999: 42-43). Moser (2012) finds that most inventions shown at the 1851 Crystal Palace exhibition were not patented in the UK or in the United States. On the other hand, many patents in the UK appear to have been obtained in fields with relatively little technological innovation (MacLeod, 1988). To explain why patents did not seem to play a more central role, Mokyr (2009) argues that formal institutions have been overemphasized and highlights, instead, private institutions that encouraged knowledge sharing. Our analysis suggests a complementary possibility: perhaps many of the new technologies of the Industrial Revolution were constrained by shortages of people with needed practical knowledge and skills, diminishing the importance of excludability while increasing the importance of knowledge exchange. This skill constraint may have been particular significant in the area of mechanical engineering (MacLeod and Nuvolari, 2009).

In any case, our analysis has a clear policy implication: innovation policy needs to adapt to different conditions, especially for early-stage technologies. In this context, the formulation of interventions ensuring knowledge sharing activities could take place and flourish may represent a very effective innovation policy strategy.

\section{Acknowledgment}

We would like to thank two anonymous referees and seminar participants at NBER, UC Berkeley and Davis, and Stanford for comments.

\section{References}

Allen, D. W. E. and J. Potts (2016), 'How innovation commons contribute to discovering and developing new technologies,' International Journal of the Commons, 10(2), 1035-1054.

Allen, R. C. (1983), 'Collective invention,' Journal of Economic Behaviour and Organization, 4(1), 1-24.

Allen, R. C. (2018), 'The handloom weaver and the power-loom: a Schumpeterian perspective,' European Review of Economic History, 22(4), 381-402. [10.1093/ereh/hex030]

Andrew, J., J. Tann, C. MacLeod and J. Stein (2000), 'Steam power patents in the nineteenth century-innovations and ineptitudes,' Transactions of the Newcomen Society, 72(1), 17-38.

Bagnall, W. R. (1893), The Textile Industries of the United States: Including Sketches and Notices of Cotton, Woolen, Silk, and Linen Manufacturers in the Colonial Period, Vol. 1. The Riverside Press: Cambridge. 
Barton, D. B. (1969), The Cornish Beam Engine. D. B. Barton: Truro.

Benkler, Y. (2017), 'Law, innovation and collaboration in a networked economy and society,' Annual Review of Law and Social Science, 13(1), 231-250.

Bennett, M. G. (1995), 'US Steel Edgar Thomson Works,' HAER No. PA-384. Historical American Engineering Record, National Park Service, US Department of the Interior.

Bessemer, H. (1905), Sir Henry Bessemer F.R.S.: An Autobiography. Offices of Engineering: London.

Bessen, J. (1999), 'Real options and the adoption of new technologies,' On-line Working Paper at http://www.researchoninnovation. org/realopt.pdf.

Bessen, J. (2003), 'Technology and learning by factory workers: the stretch-out at Lowell, 1842,' Journal of Economic History, 63, 33-64.

Bessen, J. (2011), 'The two faces of innovation,' Boston University School of Law Working Paper 10-35 (previously titled 'Communicating Technical Knowledge'), http://ssrn.com/abstract=1698802

Bessen, J. (2012a), 'More machines, better machines. . or better workers?' Journal of Economic History, 72(1), 44-74.

Bessen, J. (2012b), 'Was mechanization deskilling?,' Boston Univ. School of Law Working Paper No. 11-13.

Bessen, J. and A. Nuvolari (2016), 'Knowledge sharing among inventors: some historical perspectives,' in D. Harhoff and K. Lakhani (eds), Revolutionizing Innovation: Users, Communities and Open Innovation. MIT Press: Cambridge, MA.

Boldrin, M. and D. Levine (2008), Against Intellectual Monopoly. Cambridge University Press: Cambridge.

Braguinsky, S. and D. Rose (2009), 'Competition, cooperation, and the neighboring farmer effect,' Journal of Economic Behavior and Organization, 72(1), 361-376.

Brems, H. (1968), Quantitative Economic Theory: A Synthetic Approach. Wiley: New York, NY.

Burke, E. (1847), List of Patents for Inventions and Designs Issued by the United States from 1790 to 1847. Gideon: Washington.

Carnegie, A. (1920), The Autobiography of Andrew Carnegie. Houghton Mifflin Company: Boston.

Casson, H. N. (1907), The Romance of Steel: The Story of a Thousand Millionaires. A. S. Barnes \& Co: New York, NY.

Chari, V. V. and H. Hopenhayn (1991), 'Vintage human capital, growth, and the diffusion of new technology,' Journal of Political Economy, 99(6), 1142-1165.

Dasgupta, P. and J. Stiglitz (1980), 'Industrial structure and the nature of innovative activity,' Economic Journal, 90(358), 266-293.

Draper, G. (1907), Labor Saving Looms, 3rd edn. Draper Corporation: Hopedale.

Ferguson, H. T. (1873), 'On the mechanical appliances used for dressing tin and copper ores in Cornwall,' Proceedings of the Institution of Mechanical Engineers, 26, 98-157.

Frankel, M. (1955), 'Obsolescence and technological change in a maturing economy,' American Economic Review, 45, $296-319$.

Fritz, J. (1912), The Autobiography of John Fritz. American Society of Mechanical Engineers: New York, NY.

Gambardella, A. and B. Hall (2006), 'Proprietary versus public domain licensing of software and research products,' Research Policy, $35(6), 875-892$.

Gibb, G. (1950), The Saco-Lowell Shops: Textile Machinery Building in New England 1813-1949. Russell \& Russell: New York, NY.

Gilroy, C. (1844), The Art of Weaving by Hand and by Power. George D. Baldwin: New York, NY.

Gordon, R. B. (1992), 'The “Kelly” converter,' Technology and Culture, 33(4), 769-779.

Harhoff, D., J. Henkel and E. von Hippel (2003), 'Profiting from voluntary information spillovers: how users benefit from free revealing their innovations,' Research Policy, 32(10), 1753-1769.

Harris, T. R. (1966), Arthur Woolf, the Cornish Engineer, 1766-1837. D. B. Barton: Truro.

Harris, T. R. (1977), 'Some lesser known Cornish engineers,' Journal of the Trevithick Society, 5, $27-65$.

Hills, R. (1989), Power from Steam. A History of the Stationary Steam Engine. Cambridge University Press: Cambridge.

Holley, A. L. (1866), 'The Bessemer process in America,' in Engineering, Vol. 5, pp. 308.

Jeans, J. (1880), Steel: Its History, Manufacture, Properties, and Uses. E \& F. N. Spon: London.

Jenkins, R. (1932), 'A Cornish engineer: Arthur Woolf, 1766-1837,' Transactions of the Newcomen Society, 13(1), 55-73.

Jeremy, D. J. (1981), Transatlantic Industrial Revolution: The Diffusion of Textile Technologies between Britain and America, 1790-1830. Mit Press: Cambridge, MA.

Jovanovic, B. and S. Lach (1989), 'Entry, exit and diffusion with learning by doing,' American Economic Review, 79, 690-699.

Jovanovic, B. and G. MacDonald (1994), 'The life-cycle of a competitive industry,' Journal of Political Economy, 102(2), $322-347$.

Kamien, M. and N. Schwartz (1972), 'Timing of innovations under rivalry,' Econometrica, 40(1), 43-60.

Knight, D. (1992), Humphry Davy: Science and Power. Blackwell: Oxford.

Lampe, R. and P. Moser (2010), 'Do patent pools encourage innovation? Evidence from the nineteenth century sewing machine industry,' Journal of Economic History, 70(4), 898-920.

Layer, R. G. (1995), Population and Labor Earnings of Cotton Mill Operatives, 1825-1914. Harvard University Press: Cambridge, MA.

Lee, T. and L. Wilde (1980), 'Market structure and innovation: a reformulation,' Quarterly Journal of Economics, 94(2), 429-436. 
Lerner, J. and J. Tirole (2003), 'Some simple economics of open source,' Journal of Industrial Economics, 50(2), $197-234$.

Levin, R. C., A. K. Klevorick, R. R. Nelson, S. G. Winter, R. Gilbert and Z. Griliches.(1987), 'Appropriating the returns from industrial research and development,' Brookings Papers on Economic Activity, 3, 783-831.

Loury, G. C. (1979), 'Market structure and innovation,' Quarterly Journal of Economics, 93(3), 395-410.

MacLeod, C. (1988), Inventing the Industrial Revolution. The English Patent System, 1660-1800. Cambridge University Press: Cambridge, MA.

MacLeod, C. and A. Nuvolari (2009), 'Glorious times": the emergence of mechanical engineering in early industrial Britain, c. 1700-1850,' Brussels Economic Review, 52, 215-237.

Mass, W. (1989), 'Mechanical and organizational innovation: the drapers and the automatic loom,' Business History Review, 63(4), 876-929.

McHugh, J. (1980), Alexander Holley and the Makers of Steel. Johns Hopkins University Press: Baltimore, MD.

Meyer, D. R. (2006), Networked Machinists: High-Technology Industries in Antebellum America. Johns Hopkins University Press: Baltimore, MD.

Meyer, P. (2003), 'Episodes of collective invention,' US Bureau of Labor Statistics Working Paper 368. Bureau of Labor Statistics, US Dept. of Labor.

Mokyr, J. (1976), 'Growing-up and the industrial revolution in Europe,' Explorations in Economic History, 13(4), 371-396.

Mokyr, J. (1999), The British Industrial Revolution. Westview Press: Boulder, CO.

Mokyr, J. (2009), The Enlightened Economy. An Economic History of Britain, 1700-1850. Yale University Press: New Haven, CT.

Morison, E. (1966), Men, Machines and Modern Times. MIT Press: Cambridge, MA.

Morison, T. A. (1980), Cornwall's Central Mines. The Northern District, 1810-1895. Alison Hodge: Penzance.

Montgomery, J. (1840), A Practical Detail of the Cotton Manufacture of the United States of America. John Niven: Glasgow.

Moser, P. (2012), 'Innovation without patents. Evidence from world fairs,' Journal of Law and Economics, 55(1), 43-74.

Nordhaus, W. D. (1969), 'An economic theory of technological change,' The American Economic Review, 59, 18-28.

North, D. C. (1981), Structure and Change in Economic History. Norton: New York, NY.

Nuvolari, A. (2004), 'Collective invention during the British Industrial Revolution: the case of the Cornish pumping engine,' Cambridge Journal of Economics, 28(3), 347-363.

Nuvolari, A. and B. Verspagen (2007), 'Lean's engine reporter and the development of the Cornish engine: a reappraisal,' Transactions of the Newcomen Society, 77(2), 167-189.

Nuvolari, A. and B. Verspagen (2009), 'Technical choice, innovation and British steam engineering, 1800-1850,' Economic History Review, 62(3), 685-710.

Parente, S. L. (1994), 'Technology adoption, learning-by-doing and economic growth,' Journal of Economic Theory, 63(2), 346-369. Pole, W. (1844), A Treatise on the Cornish Pumping Engine. Weale: London.

Penin, J. (2007), 'Open knowledge disclosure: an overview of the evidence and motivations,' Journal of Economic Surveys, 21, 326-347.

Powell, W. and E. Giannella (2010), 'Collective invention and inventor networks,' in B. Hall and N. Rosenberg (eds), Handbook of Economics of Innovation, Vol. 1. Elsevier: Amsterdam.

Quandt, R. E. (1960), 'Tests of hypotheses that a linear system obeys two separate regimes,' Journal of the American Statistical Association, 55(290), 324-330.

Reinganum, J. F. (1983), 'Uncertain innovation and the persistence of monopoly,' American Economic Review, 73, 741-748.

Rosenberg, N. (1976), Perspectives on Technology. Cambridge University Press: Cambridge, MA.

Rosenberg, N. (1982), Inside the Black Box: Technology and Economics. Cambridge University Press: Cambridge, MA.

Rossiter, R. (1896), 'Pittsburg meeting of the American Institute of Mining Engineers,' Engineering News and American Railway Journal, 35, 135-136.

Rowe, J. (1953), Cornwall in the Age of the Industrial Revolution. Cornish Hillside: St. Austell.

Salter, W. E. G. (1960), Productivity and Technical Change. Cambridge University Press: Cambridge, MA.

Spargo, T. (1865), The Mines of Cornwall and Devon. Victoria Press: London.

Temin, P. (1964), Iron and Steel in Nineteenth-Century America: An Economic Inquiry. MIT Press: Cambridge, MA.

Thomson, R. (2009), Structures of Change in the Mechanical Age. Technological Innovation in the United States, 1790-1865. Johns Hopkins University Press: Baltimore, MD.

Todd, A. C. (1967), Beyond the Blaze. A Biography of Davies Gilbert. D. B. Barton: Truro.

Wallace, A. F. (1978), Rockdale: The Growth of an America Village in the Early Industrial Revolution. Knopf: New York, NY.

Ware, C. (1931), The Early New England Cotton Manufacture. Houghton Mifflin: Boston, MA.

Williamson, J. G. (1971), 'Optimal replacement of capital goods: the early New England and British textile firm,' Journal of Political Economy, 79(6), 1320-1334.

Zevin, R. B. (1971), 'The growth of cotton textile production after 1815,' in R. Fogel and S. Engerman (eds), The Reinterpretation of American Economic History. Harper and Row: New York, NY. 